\title{
The Accountant's Role In Supporting A Legal Prosecution
}

Gilbert Barrera, JD, CPA, Texas A\&M University-San Antonio, USA
Dennis Elam, PhD. CPA, Texas A\&M University-San Antonio, USA

\begin{abstract}
This paper lays out a logical framework for the Accountant to assist a prosecutor in preparing a criminal case. It utilizes the example of an employee theft. It suggests analyzing what laws have been broken to establish an outline for the supporting documents. While the Accountant will likely understand the internal controls and employee training which will form the basis of the prosecution's case, the lawyer will not be so familiar with the process. By laying out the legal case underpinned by the internal controls and procedures broken by the employee, the case will be better understood by both the prosecutor and the jury.
\end{abstract}

Keywords: Fraud; Evidence; Law Enforcement; Criminal Prosecution; Affidavits

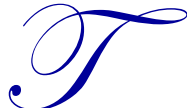

raditionally, an Accountant provides internal information critical to management's decisions. In today's global, borderless business world, additional functions loom large for today's Accountant: enforcement of ethical standards, prevention and detection of fraud, preparation of documentary evidence, and preparation for testimony as an expert witness. This article demonstrates how useful the Accountant can be in a forensic setting.

The hypothetical used in this article involves law, facts, and circumstances that are often encountered in every state and at the federal level in the United States. Within these jurisdictions the methodology illustrated herein can be employed with little or no variation. For example, all state and federal jurisdictions have a rule of evidence that is similarly worded, and which has the purpose of allowing business records into evidence in a criminal or civil case. Such records will be admitted into evidence provided they meet certain legal requirements (as explained below). ${ }^{1}$ These legal requirements seek to prohibit inadmissible hearsay from being admitted into evidence. ${ }^{2}$ Of course, the Accountant must confer with the relevant law enforcement agencies on each and every case to make sure that the documentary evidence is gathered in a manner that allows for admission into evidence. As for jurisdictions outside the United States, differences in the law will have a more pronounced affect on how this methodology is employed. For example, in Germany, hearsay is admissible in a criminal case. Thus, consideration must be given to determine how the accounting records will be presented in a German court of law as opposed to an American court of law.

${ }^{1}$ Fed. R. Evid. 803(6):

The following are not excluded by the rule against hearsay, regardless of whether the declarant is available as a witness: ...

(6) Records of a Regularly Conducted Activity. A record of an act, event, condition, opinion, or diagnosis if:

(a) the record was made at or near the time by--or from information transmitted by--someone with knowledge;

(b) the record was kept in the course of a regularly conducted activity of a business, organization, occupation, or calling, whether or not for profit;

(c) making the record was a regular practice of that activity;

(d) all these conditions are shown by the testimony of the custodian or another qualified witness, or by a certification that complies with Rule 902(11) or (12) or with a statute permitting certification; and

(e) neither the source of information nor the method or circumstances of preparation indicate a lack of trustworthiness.

${ }^{2}$ Fed. R. Evid. 801. Definitions That Apply to This Article; Exclusions from Hearsay

(a) Statement. "Statement" means a person's oral assertion, written assertion, or nonverbal conduct, if the person intended it as an assertion.

(b) Declarant. "Declarant" means the person who made the statement.

(c) Hearsay. "Hearsay" means a statement that:

(1) the declarant does not make while testifying at the current trial or hearing; and

(2) a party offers in evidence to prove the truth of the matter asserted in the statement

Copyright by author(s); CC-BY 
Criminal cases vary in complexity from a straightforward employee-theft to a case involving financial statement fraud or securities fraud. However, the appearance of simplicity can often be deceiving. For example, you may wonder why an Accountant's assistance is needed on an employee-theft case when the employee, while on the job, is on video stealing a television that is still in the box. The theft is perpetrated against his employer, an electronics store. If the case is a theft, then the severity of the offense depends on the value of the property stolen, which calls for proof beyond a reasonable doubt that the box did have the stolen television in it. A defense attorney will usually argue that the employee is on video carrying an empty box because the employee was just taking the empty box outside to throw it away. Alternatively, the defense attorney may claim that if there was a television in the box it was worth less than the amount necessary for the court to have jurisdiction. Still another defense might claim that the box had inventory other than the television as described in the indictment. If the value of the inventory is $\$ 1,499.99$ and the case has been filed in a district court whose minimum jurisdiction is $\$ 1,500.00$, the defendant-employee will not be found guilty of anything because the court lacks jurisdiction to hear this case by the amount of $\$ .01$. If the defense can show that inventory other than a television was in the box, but the indictment alleges that a television was stolen, then the employee will be found guilty of nothing because the proof does not conform to the allegation. In such an employee-theft case, documents such as purchase orders, invoices, requisition forms, and inventory subsidiary ledgers need to be authenticated in a court of law by a witness who has knowledge of these documents to establish the ownership, nature, cost, and value of the inventory in the box. This is characteristically accomplished through a rule of evidence, found in federal and states' rules of evidence, called the business records exception to the hearsay rule.

In the initial stage of investigation of a criminal case, law enforcement will confer with witnesses including Accountants. At this point, there is characteristically a communication gap between law enforcement and the Accountant. The reason is simple: law enforcement doesn't understand accounting, and the Accountant doesn't understand the applicable law. The end result is a file ultimately assembled by law enforcement, with input from the Accountant, but which takes the prosecutor a great deal of time to decipher in order to present to the grand jury for indictment. Law enforcement is accustomed to presenting the prosecutor with a file that is in chronological order, which is acceptable for a file that does not involve numerous documents. However, a file that does involve numerous documents is best organized based upon the elements of the offense.

The solution involves the Accountant taking the initiative to understand a little law. Specifically, the Accountant first needs to ask law enforcement what crime, or crimes, are involved. Then, the Accountant should find that criminal statute and organize information based upon the elements of that particular offense.

For example, to continue with the hypothetical of the employee on video who steals a television still in its box, while exact wording varies from state to state, Texas Penal Code $\$ 31.03$ defines theft as follows (the given definitions have been abbreviated to maintain relevance to this article):

A person commits an offense if he: unlawfully appropriates

a) "Appropriate" means to acquire or otherwise exercise control over property other than real property.

2) property

a) "Property" means tangible or intangible personal property

3) with intent to deprive

a) "Deprive" means to withhold property from the owner permanently or for so extended a period of time that a major portion of the value or enjoyment of the property is lost to the owner;

4) the owner of property

a) "Owner" means a person who has title to the property, possession of the property, whether lawful or not, or a greater right to possession of the property than the actor; 
The job of the Accountant would be to provide evidentiary support, using the underlined four "elements" of the offense, as the table of contents for the work product to be submitted to law enforcement. Within each element, the Accountant should include copies of accounting records, copies of original documentation, affidavits, flow charts of internal controls, and explanations of internal control procedures as needed.

To further elaborate on the employee-theft case in Texas, the following documentation for each element of the offense of theft would include the following (Note that each list of evidence directly supports one of the four "elements' of the offense.):

1)

unlawfully appropriates

a) Copy of video showing the theft;

b) An affidavit from the operator of the video that the video equipment was in working order on the date of the offense, that the attached video is a true and accurate depiction of the events recorded, and the attached copy of the video has been initialed by the affiant signifying the review of the entire video;

c) An affidavit from the owner (see below) or a witness in narrative form stating:

i. what happened and when (which should agree with the video); and

ii. a description of the property (identified by serial number if applicable) which should agree with "property" mentioned below;

d) An affidavit from the owner stating:

i. he/she wishes to prosecute and will fully cooperate; and

ii. the employee did not have the authority to take the property

2) property

a) An affidavit from the Accountant that fulfills the requirements of the business records exception to the hearsay rule, and which is accompanied by any and all copies of accounting records and original documentation that establish when the owner acquired the property, its location, cost, fair market value and serial number. Generally, the affidavit fulfills the requirements of the business records exception to the hearsay rule if it states:

i. The custodian of records by name;

ii. The number of pages of business records attached to it;

iii. It is the regular course of the employer's business to maintain these records;

iv. It is the regular course of the employee to maintain these records for the employer;

v. The records were made at or near the time that the transaction occurred, by someone with personal knowledge of the transaction and who regularly transmits the records to the custodian of records. It is permissible, but not required, for the custodian of records to have personal knowledge of the transactions. A successor custodian of records is competent to testify as such, however the successor must also provide an affidavit in the successor's name.

b) An affidavit from the Accountant which explains the significance of the accounting records as well as the internal controls and inventory controls that eliminate the possibility that the box was empty, or contained a different type of inventory, when the theft occurred.

3) with intent to deprive

a) Affidavit from the Accountant, or owner, which explains that the stolen property is still missing, or period of time it was missing.

4)

the owner

a) Note that there can be more than one "owner" because "owner" is anyone who has a greater right to possession of the property than the thief. This means that the owner can be the owner of the business, a manager, an Accountant, or others who had charge of the safekeeping of the property at the time it was stolen. It can include a successor as long as the successor is identified as the owner in the indictment. 
Affidavits obtained from witnesses, other than the custodian of records affidavit, should not include words such as “. . . I was told ...", or "... I heard ...", which indicate inadmissible hearsay. Such affidavits need to be written in a clear and concise manner so that a layperson can understand them. Proofreading of affidavits, spreadsheets, and copies of accounting records is essential to avoid unintended misinterpretations, and to avoid errors in footed or crossfooted totals. An error of this sort is extremely difficult to overcome.

If you have the impression that you are doing most of the work for law enforcement, you are correct. Although the Accountant may not have witnessed the theft, the Accountant understands the accounting records and can come to appreciate their evidentiary value as proof in a criminal case. This proof is necessary to establish that the box the employee had was not empty, that the employer was the owner of the inventory at the time of appropriation, and that the fair market value of the inventory was the amount as alleged in the indictment. Regardless of the jurisdiction or particular crime, the Accountant's assistance to law enforcement in this manner will enhance the prosecution's ability to prove the case beyond a reasonable doubt, it will expedite the indictment of the case, and it will also strengthen the plea bargaining position of the case.

\section{AUTHOR INFORMATION}

Gilbert Barrera earned a BA in English as well as his Juris Doctor from St. Mary's University in San Antonio, TX. He also earned a BBA in Accounting and an MPA in Accounting with emphasis in Tax from the University of Texas at San Antonio. He is currently teaching at Texas A\&M-San Antonio. He is a licensed CPA and an attorney in Texas. He has twelve years experience in the Travis County Attorney's Office and eight years experience in the Bexar County Criminal District Attorney's Office. As a prosecutor, he has been lead prosecutor on approximately one hundred jury trials of various offenses including white collar crimes. He also served for two years as an Assistant Attorney General in the Tax Division of the Office of the Attorney General of the State of Texas. Additionally, he has eight years experience as a CPA and has used this experience in the investigation and prosecution of many criminal cases.

Dennis Elam earned his BBA, MBA, and PhD from the University of Texas at Austin. He has worked as a practicing CPA, comptroller, securities broker, Federal Bankruptcy Trustee, and in a family owned oil field construction business.

His weblog 'professorelam' has been named one of the Top 50 Accounting Professor Blogs in the USA. He is an associate professor at Texas A \& M University San Antonio. He is a board member of San Antonio Institute of Internal Auditors and a member of the Financial Executives International. He lives in San Antonio with wife Christy and rescued Catahoula, Bentley. 